\title{
Gonatodes caudiscutatus (Günther, 1859) (Squamata: Sphaerodactylidae): Distribution extension in Ecuador
}

\author{
Amaranta Carvajal-Campos ${ }^{*}$ and Omar Torres-Carvajal \\ 1 Pontificia Universidad Católica del Ecuador, Escuela de Ciencias Biológicas, Museo de Zoología. Apartado 17-01-2184. Quito, Ecuador. \\ * Corresponding author: E-mail: a.carvajalcampos@gmail.com
}

\begin{abstract}
Gonatodes caudiscutatus is currently known from the Pacific coast of Ecuador, the Galapagos Archipelago and Peru (all west of the Andes). Here we provide the first records of this species from the Upper Amazon Basin east of the Andes in Ecuador. We found no morphometric or meristic differences between populations east and west of the Andes except in the number of loreals (fewer on eastern populations), and in the number of supraciliary spines (more individuals with higher number of supraciliary spines on western populations).
\end{abstract}

Gonatodes currently includes 28 valid nominal species (Schargel et al. 2010; Kok 2011; Sturaro and Avila-Pires 2011) ditributed in Central and South America, and in the Antilles (Avila-Pires 1995). These lizards are diurnal (except G. antillensis), typically climbers, and present a clear sexual dichromatism in most species (except $G$. lichenosus) (Bennett and Gorman 1979; Vitt et al. 2000; Avila-Pires 1995; Rojas-Runjaic et al. 2010).

Gonatodes caudiscutatus is distributed in Ecuador and Peru (Peters and Donoso-Barros 1970; Rivero-Blanco 1979; Lehr 2002) and is characterized by the following features (according to Van Denburgh 1912; Peters and Donoso-Barros 1970): snout obtusely pointed, one and a half times the diameter of the orbit; ear opening small; rostral broader than high, pentagonal, incised on the top; small internasal on each side; supralabials six; infralabials five; pupil round; dorsolateral light bands or vertebral stripe absent; lower surface of tail with a continuous longitudinal series of enlarged scales; digits strongly compressed; head in males with variegated yellow; dorsum in males with small bluish ocelli bordered with black.

In Ecuador, Gonatodes caudiscutatus is reported from the Pacific coast west of Andes, and from the Galapagos Archipelago (Lever 2003). Herein we report on the distribution of G. caudiscutatus in continental Ecuador, including the first records east of the Andes, in the Upper Amazon Basin. Our findings are based on specimens housed at the Museo de Zoología Pontificia Universidad Católica del Ecuador (QCAZ). This study was funded by Secretaría Nacional de Ciencia y Tecnología del Ecuador (SENACYT; project PIC-08-0000470).

Terminology for morphological characters follows Van Denburgh (1912) and Avila-Pires (1995). Measurements were taken with digital calipers and recorded to the nearest $0.1 \mathrm{~mm}$ : snout-vent length (SVL) (from the tip of the snout to the anterior edge of the cloaca), head length (from the tip of the rostral to the anterior edge of the ear-opening), head depth (at the highest point of the head), head width (at the widest point of the head), length of tibia (from the knee to the ankle), femoral length (from the insertion pelvic girdle to the knee). Scale counts were taken as follows: postrostrals (in contact with the posterior edge of the rostral), postnasals (in contact with the posterior edge of the nostril), loreals (in a line between postnasals and the anterior edge of the orbit), supraciliary spines (conical scales on the anterior portion of the supraciliary flap), supralabials (enlarged scales in the upper jaw), postmentals (in contact with the posterior edge of the mental), infralabials (enlarged scales in the lower jaw), ventrals (counted along a midventral line from the anterior edge of the forelimbs to the anterior edge of the hindlimbs), Toes III and IV lamellae (counted lamellae under the third and fourth toes respectively from the ungual scale to the base of the toe). The color pattern in live specimens from eastern and western populations were determined from photographs.

Sex was determined based on color and blotch patterns. Specimens under $18 \mathrm{~mm}$ were considered juveniles in order to avoid an understimation of males (juveniles and females present a highly similar coloration and blotch patterns). To test if the morphometric and meristic measurements vary among Gonatodes caudiscutatus populations (west and east of the Andes) a MANOVA for morphometric characters and Mann-Whitney U tests - for meristic characters were performed. Prior to those analyses, normality was checked with the Shapiro-Wilk test and homogeneity with box-plots.

Along the Pacific coast G. caudiscutatus is common and occurs at provinces of Santo Domingo de los Tsáchilas, Guayas, Los Ríos, and Manabí between 0-900 m. East of the Andes the species occur at higher elevations in Río Negro (QCAZ 5991-5, 6002, 6301-2), 01⒉ $4^{\prime} 0^{\prime \prime}$ S, 78¹3'0" W, $1250 \mathrm{~m}$, Provincia Tungurahua; Limón and surroundings (QCAZ 4187-9, 8664), 02 $59^{\prime \prime} 0^{\prime}$ S, 78²2'0” W, 1090 $\mathrm{m}$, Provincia Morona Santiago; and in Zamora (QCAZ 8650), 04 $4^{\circ} 9^{\prime \prime}$ S, 78 57'24" W, 970 m, Provincia Zamora- 
Chinchipe (Figure 1). In addition, we note that the tissue sample of $G$. caudiscutatus used by Gamble et al. (2008) comes from a specimen (KU 218359) collected in Limón, Provincia Morona-Santiago (we have not examined the specimen). Among specimens collected east of the Andes, QCAZ 8650 was found at 12:30 basking on a wall; QCAZ 4187-9, 8664 were collected around 12:00-13:00 between corrugated roof sheets against a house, approximately $1 \mathrm{~m}$ above the ground; QCAZ 4187-9, 8664 were found on the grass near a wall.
Geographic variation in meristic and morphometric characters of $G$. caudiscutatus are presented in Tables 1 and 2 . The results of the MANOVA for morphometric characters were as follows: $\mathrm{N}=23$; df: 17 ; Pillai's Trace: value $=0.282, F$ $=1.047, P=0.432$. Loreals and supraciliary spines differed significantly among samples $(\mathrm{N}=29$; Mann-Whitney $\mathrm{U}$ value $=52.000, P=0.29$; Mann-Whitney $U$ value $=59.500$, $P=0.039$; respectively), eastern individuals had fewer loreals and supraciliary spines than western individuals (East: 8-13 loreals and 0-3 supraciliary spines; West: 10-

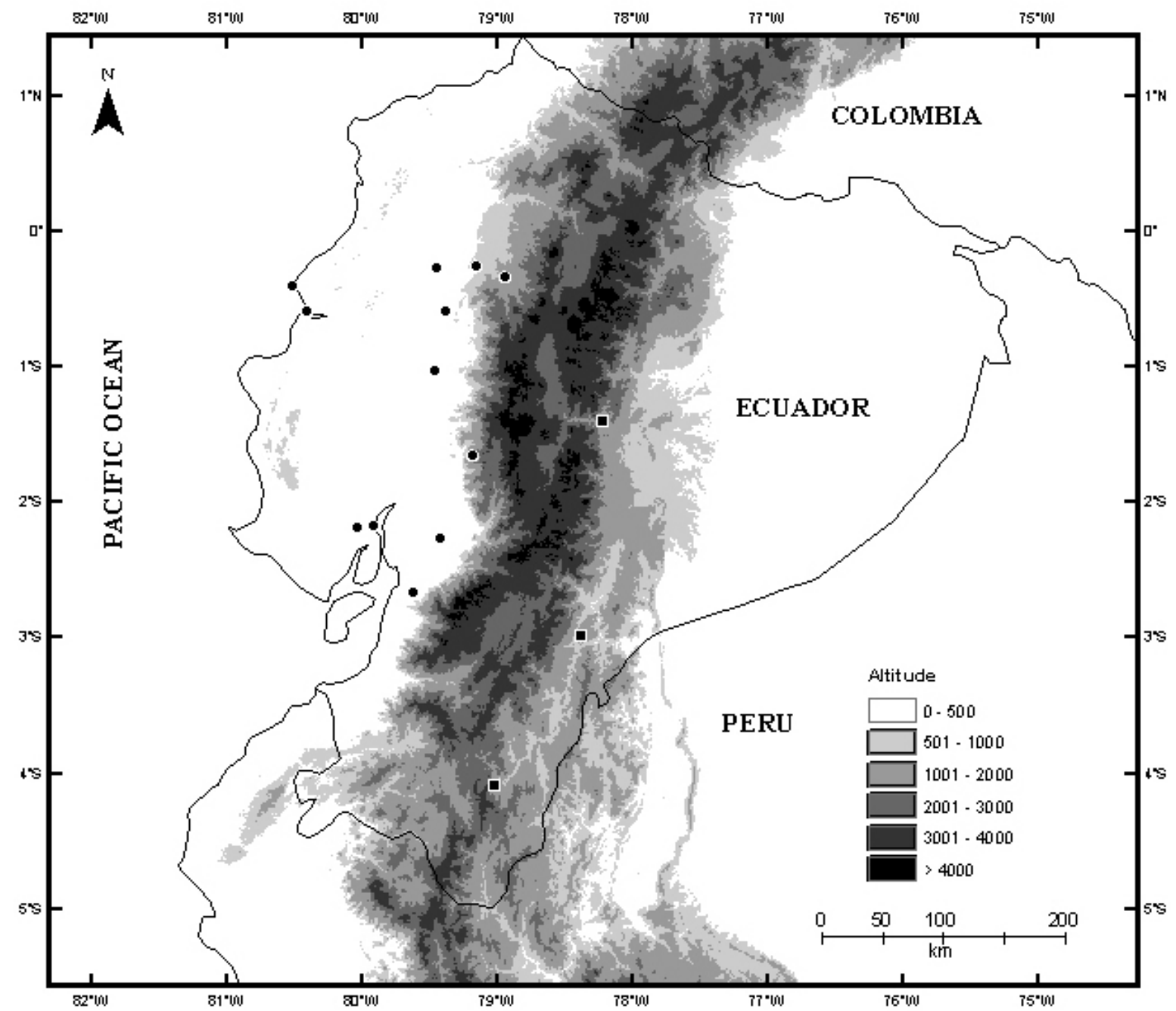

FIGURE 1. Distribution of Gonatodes caudiscutatus in continental Ecuador. Altitude in meters. Eastern localities: squares, Western localities: circles.

TABLE 1. Summary of morphometric characters (in milimeters) of eastern and western populations of Gonatodes caudiscutatus in Ecuador. For each morphometric character the F-value, and corresponding P-values are given. Range and sample size (first line), and mean \pm standard deviation (second line) are given. SVL = snout-to-vent-length.

\begin{tabular}{lcccc}
\hline & EAST & WEST & F & P \\
\hline SVL & $20.12-40.00(8)$ & $28.5-44.05(17)$ & & \\
& $32.87 \pm 7.25$ & $3.96 \pm 5.2$ & 0.470 & 0.501 \\
Head depth & $3.63-5.00(8)$ & $4.08-5.18(16)$ & & \\
& $4.20 \pm 0.43$ & $4.08 \pm 0.61$ & 0.076 & 0.786 \\
Head & $8.22-9.50(8)$ & $7.10-10.35(16)$ & & \\
length & $8.65 \pm 0.51$ & $8.71 \pm 1.21$ & & 0.88 \\
Femur & $6.13-7.46(8)$ & $5.37-8.28(16)$ & & \\
length & $6.42 \pm 0.52$ & $6.70 \pm 0.97$ & 0.896 & 0.355 \\
Tibia & $3.75-5.90(8)$ & $3.28-6.47(17)$ & & \\
length & $4.90 \pm 0.63$ & $5.36 \pm 0.68$ & & 0.059 \\
\hline
\end{tabular}

13 loreals and 0-3 supraciliary spines). However, the small sample size may have biased the results because the count ranges of these characters overlap. Other morphometric and meristic characters do not differ significantly among eastern and western populations (Tables 1 and 2).

Color in life (color in preservative given in parentheses): Head in males with yellow (cream or yellowish) stripes, two extending from the supraorbital region to the snout, one starting on the posterior corner of the eye and continuing posteriorly, and another one starting near the tympanum and continuing to the neck; large blue (cream or bluish cream) ocellus bordered in black on each shoulder; flanks and dorsum with scattered blue (cream of bluish cream) spots; gular cream patch with brown spots in a few specimens (a less conspicuos cream patch); ventral scales dark brown; hindlimbs cream ventrally. Head in females with a similar, but less conspicuous pattern of cream 
stripes as in males; dorsum brown; venter cream, with some brown spots in the gular region; limbs and digits with brown transverse bands dorsally (Figure 2).
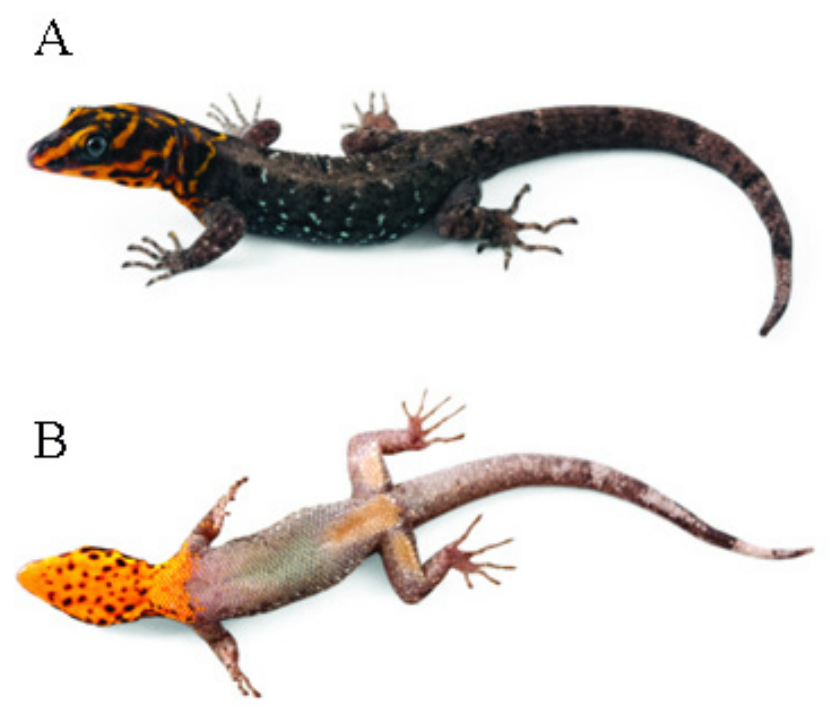

C

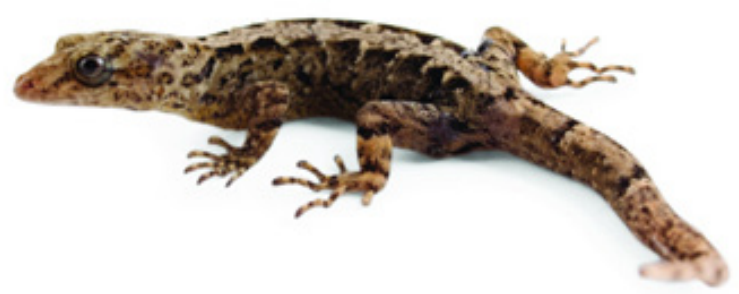

Figure 2. Male (A and B, QCAZ 10917, SVL = 38.55) and female (C, QCAZ 9826, SVL $=45.05$ ) of Gonatodes caudiscutatus from Ecuador.

TABLE 2. Summary of scale counts of eastern and western populations of Gonatodes caudiscutatus in Ecuador with corresponding Mann-Whitney $\mathrm{U}$ values and P-values. Range and sample size (first line), and mean \pm standard deviation (second line) are given.

\begin{tabular}{|c|c|c|c|c|}
\hline & EAST & WEST & $\begin{array}{c}\text { Mann- } \\
\text { Whitney }\end{array}$ & $\mathbf{P}$ \\
\hline Postnasal & $\begin{array}{c}3(12) \\
3 \pm 0\end{array}$ & $\begin{array}{c}3(17) \\
3 \pm 0.24\end{array}$ & 96.000 & 0.401 \\
\hline Postrostral & $\begin{array}{c}2-4(12) \\
3.25 \pm 0.62\end{array}$ & $\begin{array}{l}2-4(15) \\
3.13 \pm 0.6\end{array}$ & 90.500 & 0.554 \\
\hline Supralabials & $\begin{array}{c}4-6(12) \\
5.08 \pm 0.51\end{array}$ & $\begin{array}{c}4-6(17) \\
5.17 \pm 0.72\end{array}$ & 92.500 & 0.633 \\
\hline Infralabials & $\begin{array}{c}4-5(12) \\
4.42 \pm 0.51\end{array}$ & $\begin{array}{c}3-5(17) \\
4.35 \pm 0.93\end{array}$ & 96.000 & 0.773 \\
\hline Loreals & $\begin{array}{c}8-13(12) \\
10.50 \pm 1.51\end{array}$ & $\begin{array}{c}10-13(17) \\
11.76 \pm 0.68\end{array}$ & 52.000 & 0.024 \\
\hline $\begin{array}{l}\text { Supraciliary } \\
\text { spine }\end{array}$ & $\begin{array}{c}0-3(12) \\
1.58 \pm 0.62\end{array}$ & $\begin{array}{c}0-3(17) \\
2.21 \pm 0.33\end{array}$ & 59.500 & 0.039 \\
\hline Postmental & $\begin{array}{c}2-4(12) \\
2.46 \pm 0.67\end{array}$ & $\begin{array}{c}2-3(17) \\
2.22 \pm 1.87\end{array}$ & 70.500 & 0.061 \\
\hline $\begin{array}{l}\text { Lamella IV } \\
\text { toe }\end{array}$ & $\begin{array}{c}21-24(12) \\
22.75 \pm 0.96\end{array}$ & $\begin{array}{c}19-25(17) \\
22.59 \pm 2.14\end{array}$ & 100.00 & 0.927 \\
\hline $\begin{array}{l}\text { Lamella III } \\
\text { Toe }\end{array}$ & $\begin{array}{l}17-20(12) \\
18.75 \pm 1.05\end{array}$ & $\begin{array}{l}17-25(17) \\
19.70 \pm 2.22\end{array}$ & 74.500 & 0.213 \\
\hline Ventral & $\begin{array}{l}16-23(11) \\
17.73 \pm 7.25\end{array}$ & $\begin{array}{l}14-19(12) \\
16.92 \pm 5.15\end{array}$ & 76.500 & 0.696 \\
\hline
\end{tabular}

How G. caudiscutatus dispersed through the Andes from the west to the east in Ecuador is currently unknown. Nonetheless, the east-of-the-Andes specimens reported in this paper do not differ significantly in coloration, lepidosis, and morphometric characters from west-ofthe-Andes specimens (except for the number of loreals and superciliary spines) (Tables 1 and 2; Appendix 1). Although, the migration patterns are still unknown, a possible explanation of its eastern distribution could be that $G$. caudiscutatus migrated accidentally while settlers from the coast moved to these regions. Eastern G. caudiscutatus specimens have been collected nearby human settlements, and no evidence of their existence in natural conditions exists. This suggests that the eastern populations of this species in invasive and requires human settlements to survive; this assumption, however, needs further investigation.

ACKNowledgments: We are grateful to Caio Antônio Figueiredo de Andrade for suggestions.

\section{LITERATURE CITED}

Avila-Pires, T.C. 1995. Lizards of Brazilian Amazonia (Reptilia: Squamata). Zoologische Verhandelingen Leiden 299: 1-706.

Bennett, A.F. and G.C., Gorman. 1979. Population density and energetics of lizards on a tropical island. Oecologia 42: 339-358.

Gamble, T., A.M. Simons, G.R. Colli and L.J. Vitt. 2008. Tertiary climate change and the diversification of the Amazonian gecko genus Gonatodes (Sphaerodactylidae, Squamata). Molecular Phylogenetics and Evolution 46 (1): 269-277.

Günther, A. 1859. Second list of cold-blooded Vertebrata collected by Mr. Fraser in the Andes of western Ecuador. Proceedings of the Zoological Society of London 1859 (3): 402-420.

Kok, P.J. 2011. A new species of the genus Gonatodes Fitzinger, 1843 (Reptilia: Sphaerodactylidae) from central Guyana, northern South America. Zootaxa 3018: 1-12.

Lehr, E. 2002. Amphibien und reptilien in Peru: die herpetofauna entlang des 10. Breitengrades von Peru: arterfassung, taxonomie, okologische bemerkungen und biogeographische beziehungen. Münster: Natur und Tier-Verlag. $208 \mathrm{p}$.

Lever, C. 2003. Naturalized reptiles and amphibians of the world. New York: Oxford University Press. $318 \mathrm{p}$.

Peters, J.A. and R. Donoso-Barros. 1970. Catalogue of the Neotropical Squamata: Part II: lizards and amphisbaenians. Bulletin of the United States National Museum 297: 127-132.

Rivero-Blanco, C. 1979. The neotropical lizards genus Gonatodes Fitzinger (Sauria: Spaherodactylinae). Unpublished PhD Thesis, Department of Biology, Texas A\&M University, Texas. 233 p.

Rojas-Runjaic, F.J.M., E.E. Infante-Rivero, P. Cabello and P. Velozo. 2010. A new non-sexually dichromatic species of the genus Gonatodes (Sauria: Sphaerodactylidae) from Sierra de Perijá, Venezuela. Zootaxa 2671: 1-16.

Schargel, W.E., G.A. Rivas, R. Makowsky, J. Celsa Señaris, M.A. Natera, T.R. Barros, C.R. Molina and C.L. Barrio-Amorós. 2010. Phylogenetic systematics of the genus Gonatodes (Squamata: Sphaerodactylidae) in the Guayana region, with description of a new species from Venezuela. Systematics and Biodiversity 8 (3): 321-339.

Sturaro, M.J. and T.C.S. Avila-Pires 2011. Taxonomic revision of the geckos of the Gonatodes concinnatus complex (Squamata: Sphaerodactylidae), with description of two new species. Zootaxa 2869:1-36.

Van Denburgh, J. 1912. Expedition of the California Academy of Sciences to the Galapagos Islands, 1905-1906. In: VI The Geckos of the Galapagos Islands. Proceedings of the California Academy of Sciences 1: 405-430.

Vitt, L.J., R.A. Souza, S.S. Sartorius, T.C.S. Avila-Pires and M.C. Espósito. 2000. Comparative ecology of sympatric Gonatodes (Squamata: Gekkonidae) in western amazon of Brazil. Copeia: 83-95.

RECEIVED: May 2011

ACCEPTED: April 2012

PUBLISHED ONLINE: June 2012

EDITORIAL RESPONSIBILITY: Pedro L. V. Peloso 